\title{
A VASSOURA, A SIMPATIA E A ESPADA: Imagens da democracia brasileira nos anos 50
}

\author{
Marlise Regina Meyrer*
}

\section{Resumo}

O artigo se propõe a estudar a representação da democracia brasileira nos anos 50 , através da análise das fotorreportagens da revista $O$ Cruzeiro. A partir das reportagens sobre os três personagens políticos que apareceram com maior frequência na revista no período estudado - Jânio Quadros, Juscelino Kubitscheck e Henrique Teixeira Lott - procuramos identificar os valores defendidos e difundidos pelo periódico com relação a política e políticos da época, contribuindo, assim, para a construção de uma imagem específica da democracia brasileira nos anos 50. A análise levou em consideração a especificidade das fontes, ou seja, fotorreportagens, as quais constituem-se em um texto predominantemente visual.

Palavras-chave: Democracia - Imagem - Representação - Fotorreportagem - Revista O Cruzeiro.

\section{THE BROOM, THE SIMPATHY AND THE SWORD: images of brazilian-democracy in the fifties}

\begin{abstract}
This article studies the representation of Brazilian democracy in the fifties, through the analysis of the photojournalism in $O$ Cruzeiro magazine. Based on articles on three politicians, frequently mentioned in the magazine during the time period studied - Jânio Quadros, Juscelino Kubitscheck and Henrique Teixeira Loft we identified values promoted and disseminated by the magazine related to politics and politicians in this period of time, aiming to build a specific image of the Brazilian democracy in the fifties. The analysis considered the specificity of the sources, that is, articles with visual predominance over writing.
\end{abstract}

Key words: Democracy - Images - Representation - Photojournalism - O Cruzeiro magazine.

\footnotetext{
* Doutora em História pela Pontifícia Universidade Católica do Rio Grande do Sul. Professora da Universidade de Passo Fundo. E-mail: meyrer_nh@hotmail.com
} 


\section{O novo político}

O objetivo do trabalho será o de identificar as representações do campo político produzidas e reproduzidas na revista O Cruzeiro nos anos de 1950, mais especificamente entre os anos 1955-57, período de maior tiragem. A revista foi, durante muito tempo, o carro-chefe da primeira Rede de Comunicação instituída no país, ou seja, o oligopólio formado pelos Diários Associados, de propriedade de Assis Chateaubriand. O Cruzeiro inseriu-se no contexto inicial do processo de modernização dos meios de comunicação no país, no final do anos 20, que se consolidou nos anos 50. Porta-voz de um discurso modernizante, foi a primeira do gênero de circulação nacional. Foi também pioneira na utilização do fotojornalismo, inovação que passou a caracterizá-la, numa conjuntura nacional de inovações técnicas, gráficas e editoriais, que transformaram as empresas jornalísticas em empreendimentos com grande poder econômico.

Embora o periódico possuísse uma secção intitulada política, onde esses temas eram tratados de forma específica, nossa análise centra-se nas fotorreportagens sobre as referidas questões. Esta especificidade da forma faz com que as mensagens se diferenciem daquelas da secção específica, mais literária e noticiosa. A política tratada nas fotorreportagens permite, assim, uma maneira diferenciada de apropriação, uma vez que seus destinatários compõem um grupo maior e mais variado. Entendemos, como Roger Chartier (2002, p.76), que “as transformações das formas através das quais um texto é proposto autoriza recepções inéditas, portanto, cria novos públicos e novos usos”. Tratase, assim, de privilegiar a dimensão simbólica do campo político.

A fotorreportagem impunha-se como um novo modelo de jornalismo em consonância com um tempo em que a sociedade urbana se estabelecia como modo de vida hegemônico. As imagens, nesta nova realidade marcada pela aceleração do tempo, contribuíam para encurtar o caminho entre a leitura e a apreensão de informações. Desde seu surgimento, no século XIX, a fotografia emergia como uma janela para o mundo, atuando diretamente no observador e de modo sensorial, enquanto que a palavra escrita permanecia como abstração, dependente de que a pessoa lesse, compreendesse e refletisse, para então assimilar, ou não, a informação (Gava, 2006).

Na fotorreportagem a ênfase na imagem fotográfica passou a ter o mesmo valor do texto verbal, até então dominante. Nadja Peregrino (1991) afirma que na fotorreportagem há a preponderância da imagem sobre o texto escrito, não sendo ela uma simples reportagem verbal ilustrada, mas, na verdade, visual auxiliada por texto. Gava (2003) afirma que nesse 
modelo, as imagens não suplantam o texto, sendo o principal fator a diagramação, ou seja, a forma como as fotografias e textos se combinam e se completam na página. Para ele, esta combinação é que dá sentido ao texto, onde nem imagens, nem texto atuam isoladamente, mas são parte de um todo que é mais importante que as partes.

Ao adotar esta nova forma, a de investigação e o jornalismo de impacto, O Cruzeiro, conforme Juarez Bahia, “vira uma página da história do jornalismo no país” assumindo um ideal de reportagem que,

[...] valorizadas por flagrantes fotográficos de profissionais que se distinguem dos retratistas, e assinadas, as reportagens trazem a marca da investigação, da criatividade e da coragem dos repórteres. A revista notabiliza a reportagem ilustrada, documental, questionadora, cujas repercussões geralmente provocam resultados imediatos [...] elabora o mito do fotógrafo no conceito de um repórter ágil, criativo, ousado, intuitivo, dotado de um padrão perceptivo que elege o instantâneo como prioridade (Bahia, 1990,p.78).

O Cruzeiro, assim, marcava a ruptura com as formas editoriais tradicionais, que tinham no discurso verbal a fonte principal da informação, substituindo-as pela linguagem fotográfica. Para Muniz Sodré, o campo (da reportagem) foi dominado pelo O Cruzeiro, cujos fotógrafos e repórteres constituíam uma espécie de elite profissional (Carneiro, 1999).

O período entre 1945 e 1964 é definido pela historiografia como a fase democrática da história da República brasileira. O ano de 1945 é considerado um marco, tanto em nível internacional - fim da segunda guerra -, quanto nacional - fim do Estado Novo. Nesse contexto, em 12 de maio de 1945, O Cruzeiro (12 mai.,1945, p.14), publicava uma reportagem intitulada "Fim da Guerra", na qual questionava sobre qual seria a parte do Brasil nesse novo contexto. Afinal, o país integrava o grupo dos vencedores no conflito mundial, e seu apoio aos aliados deveria, agora, resultar em algum tipo de dividendos. A matéria relatava os problemas decorrentes do "estágio de subdesenvolvimento brasileiro" e projetava o Brasil do futuro, onde, segundo o repórter, ricos e pobres (cada um na sua função) vivam em harmonia.

A saudação de $O$ Cruzeiro a este novo tempo e o questionamento sobre o futuro da nação teve como contraponto o retorno de Vargas, em 1951, visto por muitos como um retrocesso, sendo que após o trágico 24 de agosto, o discurso sobre um “novo começo” foi retomado. Assim, na abertura do ano 1955, a revista O Cruzeiro, (01 jan., 1955, p.76) ao fazer um balanço dos últimos 10 anos, anunciava um novo recomeço, finalmente livre da ditadura e do ditador. Tratava-se, então, de combater o que a revista chamou de "o espectro de Vargas” ou a "República dos Coronéis”. Esta percepção de um novo tempo - 
pós suicídio - era compartilhada por muitos intelectuais da época, conforme observação da historiadora Ângela de Castro Gomes:

Para os intelectuais dos anos 1950, para os homens em geral dessa geração, ou mesmo para aqueles que pertencem a gerações anteriores ou posteriores, a idéia de um "tempo" com mais oportunidades e esperanças é bem visível e não deve ser menosprezada. A operação que delineia esse "tempo" o destaca daqueles que vêm "antes" (o do suicídio de um presidente) e "depois”(o da renúncia de um presidente, seguida de crises e de um golpe político), elegendo a figura de Juscelino como seu símbolo. (GOMES, 2002,p.13).

O novo tempo, para o Brasil, era o do desenvolvimento, da superação do atraso, sobretudo econômico. Porém esse não estava dissociado de desenvolvimento cultural e, também, político. Esse último aspecto levou a associação entre "Brasil moderno" e Brasil democrático” (Gomes, 2002, p.12).

Desenvolvimento e democracia estavam diretamente vinculados nos discursos de Juscelino Kubitscheck no período. O ideal democrático, valor político norteador da época, só poderia ser obtido pelo combate à pobreza. Esta questão esteve na base dos discursos sobre o subdesenvolvimento da América Latina. O que estava em jogo era a defesa do Ocidente capitalista, sendo que o desenvolvimento aparecia como o meio mais eficaz de garantir a ordem capitalista e a democracia. Segundo Miriam Limoeiro Cardoso (1978, p.111), no desenvolvimentismo jucelinista, "a luta pela democracia identifica-se com a luta contra a estagnação e subdesenvolvimento”.

A democracia defendida pelos Associados, rede à qual pertencia O Cruzeiro, tinha, porém, tonalidades específicas, permeada pelos interesses e convicções do grupo e de seu proprietário, Assis Chateaubriand, ele mesmo um personagem político no período. Em linhas gerais, a revista tinha uma abordagem conservadora da democracia, que excluía certas camadas da população de uma participação política efetiva e enfatizava a importância dos militares na manutenção da ordem, condenando os movimentos espontâneos organizados por estas parcelas da população. Possuía uma visão elitista da política, que deveria ser praticada por uma elite na defesa dos seus interesses, dando pouquíssima atenção às reivindicações das camadas populares.

O final dos velhos tempos foi anunciado em O Cruzeiro (03 dez., 1955, p.10), na reportagem intitulada: “Caiu a República dos Compadres”, que versava sobre a tentativa 
golpista frustrada e o contragolpe de 11 de novembro. ${ }^{1}$ Nela, Café Filho aparecia como o derradeiro político da era Vargas e dos vícios coronelistas, como “[...] o compadrismo, barateamento dos cargos, a instituição nacional do pistolão, a indústria dos cartórios, [...]”. De um modo geral, a mensagem dessa matéria era a de que a democracia havia vencido, embora sob a proteção do exército, em conformidade com a antiga concepção salvacionista da corporação, presente na sociedade brasileira. O repórter David Nasser, na matéria citada, ataca o ex-presidente Café Filho, representante da "velha ordem” :

Que o senhor João Café Filho, não tem o dom da Presidência, isso até o mais humilde potiguar o sabe. Ninguém ignorava que o seu vôo era curto, que as suas asas, não eram asas de águia, mas asas de um honesto peru de quintal. Sabíamos que o seu sonho mais alto - de prefeito da roça a vereador do sertão - fora ultrapassado com a deputação federal, mercê, talvez de sua fibra ou de sua espantosa capacidade de trabalho. Trabalho miúdo, o seu, migalhas de lei, sem a grandeza de um parlamentar verdadeiramente nacional. (O Cruzeiro, 03/12/1955,p.11).

O político, segundo essa concepção, deveria ser um profissional, não um cidadão comum. Este elitismo político é descrito por Décio Saes (1997, p.465) como um traço característico da ideologia da alta classe média. Para o autor, a luta deste grupo “[...] é a luta por impedir a transformação de direito à política em prerrogativa comum e universal, e por conservar a política como um símbolo de prestígio social.”

A partir desse entendimento, a desqualificação de Café Filho como político pareceu a arma mais adequada para atacá-lo, e a reportagem não poupa esforços nesse sentido, quando aponta, inclusive, para o baixo nível intelectual do ex-presidente, que teria dificuldades em defender seus pontos de vista diante de seus ministros, “infinitamente mais inteligentes”, dos quais seria apenas, nas palavras do jornalista, “uma marionete”, e sentencia: “no comboio presidencial, ele viajava, realmente no último carro”(O Cruzeiro, 03dez.,1955, p.11).

A reportagem apela para moralismo, afirmando que “[...] no Brasil democracia é algo que a gente gosta quando está por baixo e que a gente detesta quando está por cima. O doce, amável e hábil deputado se transmutara, mordido pela mosca do poder, num austero, doutoral

\footnotetext{
${ }^{1}$ Frente à vitória de Juscelino Kubitschek e João Goulart, a ala conservadora do exército deu início a um movimento golpista que evitasse a posse dos candidatos. Em meio à crise, o presidente Café Filho se afasta por motivos de saúde, assumindo Carlos Luz. Este faz o jogo dos militares golpistas e acaba forçando a demissão do ministro da Guerra, General Lott, que já havia declarado publicamente que defenderia, de todas as formas, a posse do presidente eleito pelo voto. No seu lugar, nomeia o general Fiúza de Castro, membro da corrente antinacionalista golpista, abrindo-se as condições para o golpe preventivo de 11 de novembro. Pressionado por diversos generais, Lott, mesmo exonerado, comanda a ocupação da capital do país por tropas do Exército, derrotando a tentativa golpista. Com isso garante a posse dos candidatos eleitos após 60 dias de Estado de sítio e a substituição de Carlos Luz pelo presidente da Câmara dos Deputados, Nereu Ramos.
} 
e frio Presidente da República” (O Cruzeiro, 03dez.,1955, p.11). A idéia de que o poder corrompe é referida por Maria Victória Benevides (1981, p.272) como uma das características do moralismo udenista. Para a autora, a falta de vocação para o poder integra harmoniosamente a imagem do partido cara aos bacharéis, a “pureza de princípios” (1981. p. 272). Sabemos que essas posições, entretanto, não eram exclusivas da UDN (nem entre os udenistas ela era unânime), mas integravam um conjunto de ideais defendidos pelas elites liberais-conservadoras ${ }^{2}$ como um todo. ${ }^{3}$

Ao finalizar a matéria, David Nasser conclui pelo “estágio” ainda atrasado da democracia brasileira:

[...] tudo isso acontece porque somos ainda uma democracia tipo Guatemala, democracia que não é um hábito, que não se fortalece na derrota eventual de um partido ou grupo de partidos, democracia que agoniza, morre e ressuscita duas, três vezes em cada geração, democracia das repúblicas centro-americanas, que necessita, para sobrevivência, do apoio das armas”( $O$ Cruzeiro, 03dez.,1955, p.11).

É nessa perspectiva que a revista $O$ Cruzeiro apoiou o contragolpe de Lott e a posterior instalação do Estado de Sítio. O objetivo, em última análise, era garantir a ordem democrática burguesa, evitando, assim, qualquer possibilidade de radicalização ou participação das massas no processo da sucessão presidencial. A disputa entre golpistas e legalistas, nessa questão, não passava de uma briga interna das elites, agrupadas de um lado na UDN e de outro, no PSD. Os militares, por sua vez, dividiam-se entre os dois grupos, porém o objetivo era o mesmo: defender a ordem democrática.

Nas fotorreportagens, essas idéias foram difundidas, sobretudo, através da eleição de alguns personagens políticos que passaram a simbolizar este modelo democrático mais afinado com a idéia de desenvolvimento e, portanto, mais próximo ao mundo civilizado. Entre os que com maior frequência apareciam na revista estão Jânio Quadros e Juscelino Kubistchek, personagens centrais na política nacional da época. Ambos passaram a

\footnotetext{
${ }^{2}$ PSD e UDN foram na sua prática política partidos conservadores. No entanto a UDN, por exemplo, tem na sua origem um discurso liberal e reúne liberais históricos em suas hostes. Sobre esta questão ver: BENEVIDES, Maria Victória de Mesquita. O Governo Kubitschek: Desenvolvimento econômico e estabilidade política. Rio de Janeiro, Paz e terra, 1979, 3ed.

${ }^{3}$ Recorremos, aqui, com frequência à caracterização utilizada por Maria Victória Benevides com relação aos udenistas, por encontrarmos estas definições respaldadas nas reportagens da revista. Entretanto, é importante observar que estas definições são por nós entendidas como referentes não exclusivamente a um partido político, mas a um grupo mais amplo, composto pelas elites e a alta classe média urbana, público-alvo de O Cruzeiro. É bom lembrar, também, que Assis Chateaubriand era senador pelo PSD, que disputava este mesmo grupo com a UDN. A própria autora citada destaca a proximidade entre os dois partidos. O que identificamos na análise das reportagens da revista é uma proximidade muito grande das ideias defendidas pela UDN.
} 
representar valores essenciais da burguesia brasileira como um todo. O primeiro tornou-se símbolo da moralização; o segundo, através de seu plano de metas, encarnava o valor do trabalho e do dinamismo necessário ao progresso, aliados a um forte carisma popular. Outro personagem que mereceu destaque foi o General Henrique Teixeira Lott, que a revista tratou de heroicizar após o 11 de novembro, trazendo-o ao discurso, vez por outra ao longo do período, como um aviso aos possíveis desvios da democracia, colocando-o como um guardião/vigilante do regime.

Sabemos que, muitas vezes, a presença desses políticos na revista tinha como principal objetivo a obtenção de algum retorno financeiro ou outra forma de privilégio ao grupo Associado. Tal constatação não invalida nossa análise, pois independente de seu objetivo imediato, o discurso das fotorreportagens produzia uma determinada imagem de democracia. O desfile de políticos, tanto amigos, quanto inimigos, construía o mesmo discurso, sendo que a ideia-força, atraso versus desenvolvimento, servia tanto para atacar adversários quanto para defender amigos. Eles apresentavam-se de forma dicotômica: o bom e o mau; o vilão e o herói.

Esta idéia está explícita na reportagem: Deputados no Banco dos Réus (O Cruzeiro, 03 nov., 1956, p.50) onde, em cinco páginas de textos e fotografias, propunha-se julgar os deputados, o que teria sido feito por 35 repórteres credenciados na Câmara dos Deputados, sorteados pelo redator da matéria. A reportagem classificou os deputados em: "os que trabalham”, “os demagogos” e “os inoperantes”. Esses tópicos aparecem em subtítulos, seguidos de séries de fotografias pequenas dos políticos que se encaixam nas referidas classificações. A fotografia legendada, com o nome e a classificação, fixava a imagem do “acusado”. Em contraposição a este grupo, na página oposta, vemos uma fotografia de página inteira, representando o político ideal (fig.01). Tratava-se do, então jovem Ulisses Guimarães, com a legenda: “Ulisses Guimarães, presidente da Câmara. Um dos mais jovens a ocupar tão elevado cargo. Trabalha 10h por dia. Tem agido bem”. (O Cruzeiro, 03 nov. 1956, p.53). 


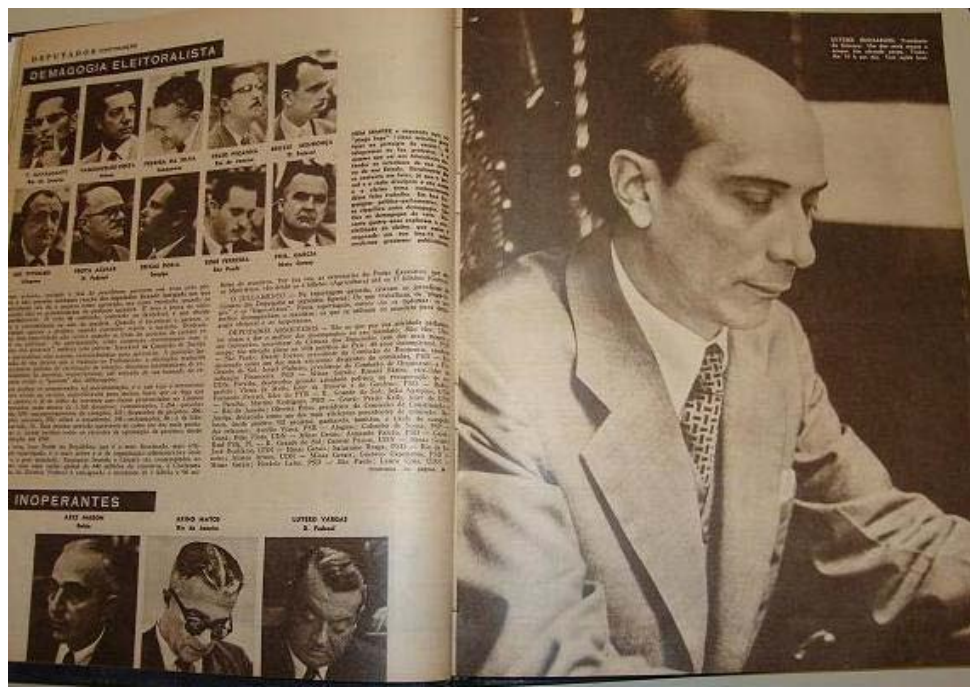

Figura 01: Deputados no Banco dos Réus. O Cruzeiro, 03 nov. 1956. p. 53.

A ideia do político ativo, do ideal do trabalho, estava em sintonia com o projeto de desenvolvimento acelerado do país. Deveriam deixar de lado a retórica, peculiar ao político tradicional, e partir para ação. A revista, assim, veiculava um discurso no qual o desenvolvimento nacional dependia de ações políticas e de políticos comprometidos com esses ideais para conduzi-lo. Lembramos que, à época, pensadores em geral, nacionalistas ou não, todos admitiam a necessidade de uma dose maior ou menor de intervenção do Estado, especialmente nas questões de infraestrutura.

Nesse sentido, através de reportagens variadas, $O$ Cruzeiro ajudou a produzir discursos que, de um modo geral, demonstravam a necessidade de mudanças de ordem política que colocassem o país em sintonia com o mundo ocidental moderno e democrático, em oposição aos regimes totalitários, cujos principais contrapontos, citados no periódico, eram a Argentina Peronista e a União Soviética.

\section{O Regime da Vassoura}

Jânio Quadros, que assumiu o governo de São Paulo no início de 1955, aparecia com frequência na revista, da qual tinha apoio político. O governador representava o salvador, empenhado em combater antigos políticos corruptos e impor uma política saneadora, racional e moderna ao Estado, em última análise, colocar “ordem no caos” (Gomes, 2002,p.33). 
O apelo teatral ${ }^{4}$ utilizado em suas campanhas favorecia a exploração deste personagem pela revista, pois se enquadrava no próprio modelo das fotorreportagens, em que os fatos desenvolviam-se como num drama e, muitas vezes, com forte apelo sensacionalista. Neste período, $O$ Cruzeiro publicou muitas matérias que enfatizavam a moralidade pública e o combate a corrupção. Podemos referir como exemplo, entre outros, a série de reportagens combatendo a importação de carros americanos, por parte dos parlamentares, com isenção de impostos, a "emenda cadillac" de 1956. De abril de 1956 a agosto de 1957, foram cinco matérias criticando tal procedimento, ${ }^{5}$ em especial, denunciando membros da "moralista” UDN que teriam votado a favor da emenda. ${ }^{6}$

O moralismo era uma das bandeiras levantadas pelos setores burgueses no período. Décio Saes (1997) situa o ápice do desenvolvimento destas ideias entre 1951-54, identificado especialmente nos discursos anti-getulistas, sobretudo da UDN, já apontado, como vimos, por Benevides. Diz a autora que as denúncias à corrupção administrativa, ou seja, os escândalos, tornaram-se a própria “razão de ser da luta oposicionista”. (Benevides, 1982, p. 267).

Outro aspecto associado a Jânio Quadros é o seu caráter populista. Neste caso, é oportuno enfatizar a aparente contradição entre o discurso da revista com relação ao populismo e o apoio dado a um líder populista. Em O Cruzeiro foram frequentes os ataques aos populismos tanto brasileiros quanto latino-americanos, sendo seus principais alvos Getúlio Vargas e Perón. Entretanto, entendemos esta questão à luz da argumentação utilizada por Benevides (1982, p.269), ao explicar o apoio da UDN - anti-populista - a Jânio Quadros. Para a referida autora, o fato é revelador sobre o tipo de populismo a ser combatido por esse grupo, ou seja, aquele relativo às massas, sobretudo ao operariado e que, na revista, justificase no intenso combate ao trabalhismo tanto getulista quanto peronista.

Jânio Quadros talvez seja o personagem mais identificado com O Cruzeiro. A ambiguidade do discurso janista, ao mesmo tempo que se propõe moderno e defensor da democracia, caracteriza seu governo por um autoritarismo personalista, desprezando as

\footnotetext{
${ }^{4}$ Benevides chama atenção para o aspecto teatral de Jânio Quadros. A respeito de suas campanhas diz: “Os palanques transformavam-se em verdadeiros palcos de tragicomédias: Jânio tomava injeções em público, simulava desmaios e comia sanduíches de mortadela levados nos bolsos. E era carregado nos ombros do povo! Numa esdrúxula mistura de radicalismo e Kitsch popularesco [...] fazia violentos ou pitorescos discursos, num português precioso de sílabas escandidas, e apoiado num visual que se tornaria típico: roupas surradas e em desalinho, cabelos compridos e barba por fazer, ombros brilhantes de caspa [...] um visionário. Muitos o tomaram como um messias, poucos denunciaram o charlatão.” BENEVIDES, Maria V. de Mesquita. O Governo de Jânio Quadros. São Paulo: Brasiliense, 1982. p.16.

${ }^{5}$ Legal, mas sujo (O Cruzeiro, 14 abr. 1956), A Marinha não faz contrabando (O Cruzeiro, 02 março 1957), A desordem vem de cima (O Cruzeiro, 04 maio 1957), Conspiração dos Cadillacs (18 maio 1957), Fronteiras e Portos do Brasil, entrada franca do contrabando de automóveis (O Cruzeiro, 31 ago. 1957).

${ }^{6}$ BENENIDES, Maria Victória de Mesquita. 1982. Op.cit. p. 269.
} 
Instituições, o que também era marca dos Diários Associados, conhecido por práticas clientelistas e por utilizar o poder de sua máquina jornalística para chantagear adversários, promover seus amigos e obter vantagens políticas e econômicas.

Nosso objetivo, aqui, não é discutir o apoio da revista a Jânio, o que nos parece evidente, mas como o personagem Jânio serviu, em parte, para a construção de uma imagem política da nação que apontava para a necessidade de renovação e de modernização, a fim de acompanhar o mesmo ritmo de desenvolvimento que estava ocorrendo em nível econômico e, ao mesmo tempo, “acertar o passo" com os países desenvolvidos. O modelo difundido pressupunha que a política deveria ser exercida por uma elite moralmente e intelectualmente qualificada para tal. O sistema defendido era de uma democracia autoritária, no estilo do clássico liberalismo brasileiro, no qual as liberdades confundiam-se, na maioria das vezes, com privilégios de grupos. Por fim, a ordem deveria prevalecer, acima de tudo, não aceitando nenhuma forma de revoltas ou agitações populares, defendendo a ideia da constante vigilância militar.

A fim de demonstrar o acima exposto, selecionamos as três maiores reportagens sobre este personagem no período: “Vinte e Oito Dias no Regime da Vassoura” (O Cruzeiro, 26 mar., 1955, p.34) O Criador de Casos (O Cruzeiro, 17 nov. 1956, p. 116) e "Tire o Chapéu a São Paulo” (O Cruzeiro, 24 ago., 1957, p. 88 e 07 dez., 1957, p. 48).

"Vinte e Oito Dias no Regime da Vassoura” é chamada da capa, já anunciada na edição anterior, dizendo que tal reportagem explicaria aos leitores, “de forma imparcial”, o que seria a tal limpeza promovida por Jânio, em São Paulo. O título principal ocupou uma página dupla, tendo como ilustração uma pequena foto de um gari, com um ar de moleque, segurando uma vassoura apontada para a câmera. Logo abaixo, sob o subtítulo "Mamatas", seguem pequenos textos que se referem a órgãos do Estado onde a limpeza está sendo realizada por conta de alguma forma de corrupção.

A última página da reportagem contém duas fotos, maiores que as demais, ocupando um espaço superior ao texto; portanto são elas que orientam o sentido da leitura (fig.02). A primeira é de dois burros, que o pequeno texto sob o título, Burros, explica fazerem parte de um lote de quarenta e nove, que foram encontrados no Departamento de Água e Esgotos e ali estavam sem função, numa evidente comparação entre os animais e os funcionários, também inativos, que o novo governo estava demitindo. No conjunto visual da página, esta foto contrapõe-se a outra, de Jânio Quadros, conversando com um dos irmãos Vilas-Boas, conhecidos sertanistas brasileiros. A legenda explica que o governador estaria tratando com o sertanista de uma excursão ao Xingu. A reportagem que inicia mostrando as medidas adotadas 
para sanear o Estado, conclui com um projeto de futuro - após arrumar a casa, poderia partir para a expansão:

[...] o jovem chefe do executivo paulista rompeu o tabu de uma geração, representa a mocidade brasileira alijada da carreira política e dos postos de comando desde 1930, na recuperação plena de seus direitos cívicos e de sua missão de dirigir os destinos da nação. (O Cruzeiro, 26 mar., 1955, p. 37).

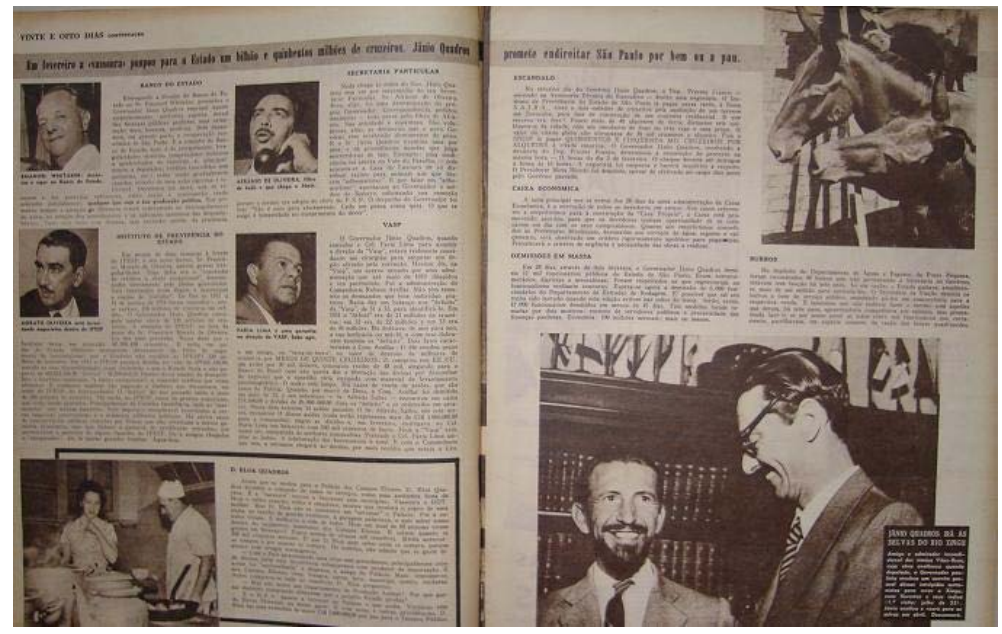

Figura 02: Vinte e Oito Dias no Regime da Vassoura. O Cruzeiro, 26 março 1955, p. 37.

A reportagem "O criador de casos” (O Cruzeiro, 17 nov. 1956, p.116) é ilustrada com pequenos desenhos de traços simples que orientam as temáticas tratadas no texto (fig. 03). A reportagem assemelha-se a um relatório administrativo ilustrado. A composição toda é muito simples, utilizando poucos recursos. A divisão em vários subtítulos e o apoio das ilustrações torna o texto de fácil “digestão”, em conformidade ao modelo "reportagem” proposto pela revista. 


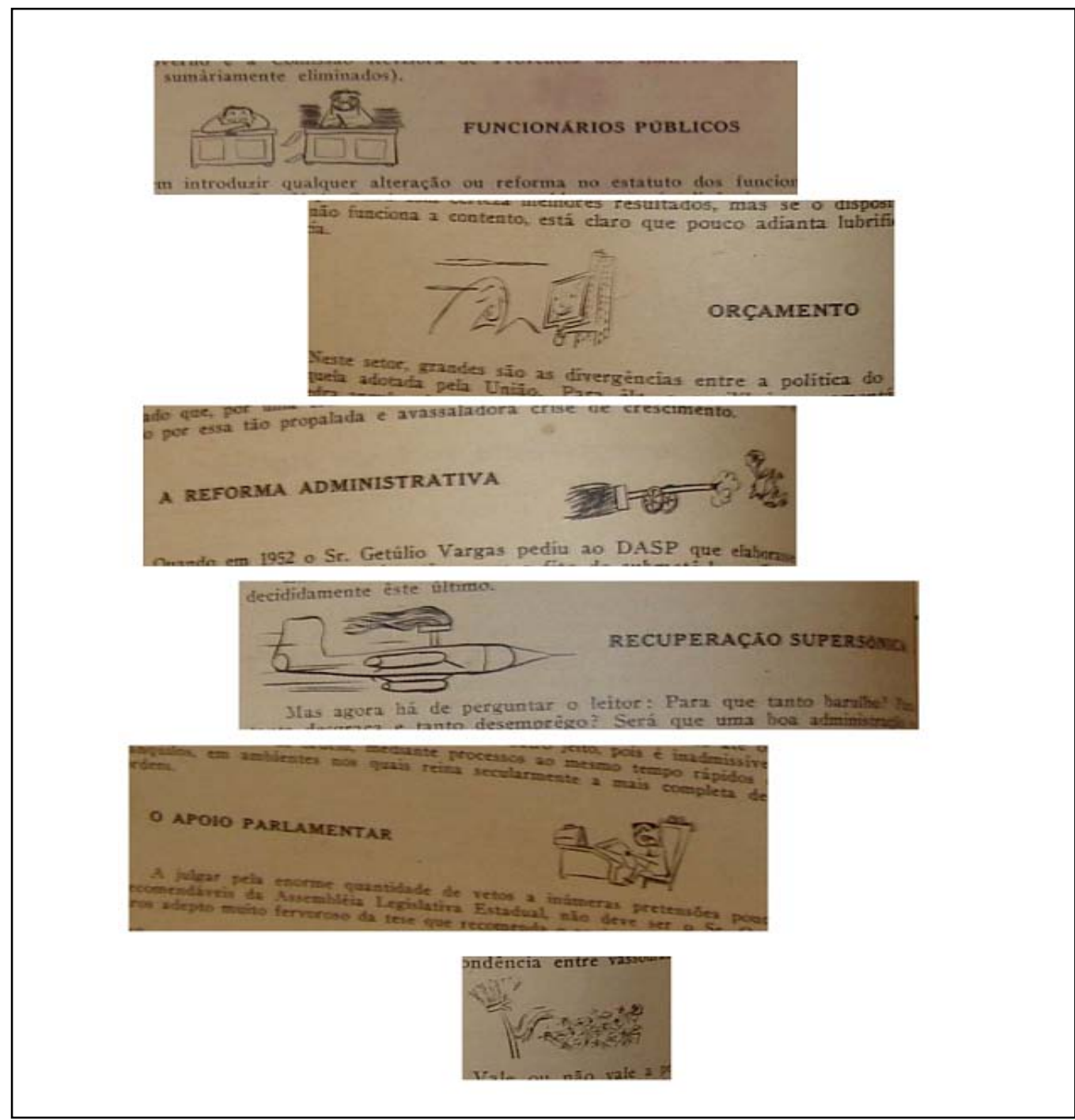

Figura 03: “ O Criador de Casos”. O Cruzeiro 17 nov., 1956, p. 116-120.

Na primeira página, à esquerda, está a fotografia de Jânio Quadros, num tom de seriedade, diante da qual é exposto o rol de medidas que ele vinha empreendendo em São Paulo. Essas estão didaticamente divididas em itens expressos nos subtítulos "Reforma Administrativa", “Orçamento”, “Funcionários Públicos”, "Vassouradas Também nos Secretários”, etc. (O Cruzeiro, 17 nov. 1956, p. 116-120).

O item "Reforma Administrativa” é ilustrado por uma vassoura estilizada em forma de um canhão atirando em uma figura, talvez um funcionário público (figura 03). O texto compara a reforma administrativa da União com a reforma feita pelo governo de SP, sendo que esta última teria se concentrado mais no motor de partida (canhão) ao invés de se preocupar com a lubrificação de toda a máquina administrativa, o que levaria muito mais 
tempo. As mudanças não poderiam depender de longos debates, deveriam ser feitas de imediato, sem muitas intermediações.

Logo a seguir, o outro item, “Orçamento”, enfatiza novamente a diferença entre a União e São Paulo. Informa que enquanto aumenta o Déficit da União, o de São Paulo diminui, devido à política saneadora janista. A ilustração acompanha a ideia do texto, constando de uma figura estilizada do Corcovado, com expressão triste, olhando-se no espelho, segurado por São Paulo (representado por altos prédios). A imagem refletida é de uma expressão de felicidade (figura 64). A sugestão é que a União deveria espelhar-se nas medidas orçamentárias de São Paulo.

O texto informa que as mudanças e o sucesso foram obtidos pelas obras de um único homem - Jânio Quadros -, confrontando as práticas administrativas do governo federal que organizou uma série de comissões de trabalho, compostas por grupos de empresários e economistas, a fim de estudar e planejar o plano de desenvolvimento nacional. A escolha de um secretário da fazenda eficiente foi descrita como mais vantajosa do que o trabalho técnico de um grupo de economistas. A matéria utilizou a imagem do gladiador como contraponto ao técnico, evidenciando a ambiguidade da democracia defendida pela revista, na qual o gladiador era ainda necessário.

O tópico "Funcionários Públicos” é ilustrado por duas mesas de trabalho, sendo que uma delas está vazia e um funcionário dorme sobre ela. Na outra, um funcionário trabalha diante uma pilha de papéis, numa alusão a funcionários operantes e inoperantes (fig. 03). O texto diz que os problemas do funcionalismo, impunidade e o desestímulo estavam sendo combatidos por Jânio Quadros através de um sistema eficaz de punições e recompensas. O autoritarismo do governador, que punia publicamente os funcionários relapsos e premiava os competentes, era elogiado pela matéria, dando ao leitor alguns exemplos específicos. A matéria citava, ainda, que o governo do Estado organizou um sistema de fiscalização através de um serviço de reclamações com denúncias por escrito e anônimas, sugerindo que todas as repartições públicas deveriam ter esse serviço.

Em "Vassouradas também nos secretários" enfatizou-se o fato de Jânio "criar casos" ao demitir alguns secretários. A ilustração mostra uma vassoura estilizada em forma humana (provavelmente Jânio Quadros), varrendo a figura de um secretário. O texto diz que no ambiente brasileiro, onde "reina secularmente a desordem", estas medidas “criadoras de casos” eram necessárias. Os “casos” criados decorriam da necessidade de tomar medidas com rapidez, o que nunca era um processo tranqilo. Portanto, na avaliação da revista, “criar casos” 
era mais apropriado e eficiente na conjuntura do Brasil da época, onde debates teóricos prolongados não resolveriam os problemas com os quais a sociedade brasileira se defrontava.

Na sequência, a defesa do autoritarismo era retomada. Sob o título "O Apoio Parlamentar”, descreveu-se a "batalha do veto” travada entre Jânio e o parlamento. Após listar vários projetos (de um modo geral, beneficiando o funcionalismo ou pedidos de verbas), o texto concluía que: "Entre o apoio parlamentar e a opinião pública, escolheu decididamente o governador esta última” (O Cruzeiro, 17 nov. 1956, p.118). Porém, aqui, a “opinião pública” não era constituída pelas massas trabalhadoras, mas pelas classes médias e altas, público leitor da revista. A imagem que ilustra este tópico mostra uma figura estilizada de Jânio em sua mesa, com expressão de indignação, segurando uma folha (em forma de vassoura), provavelmente contendo os projetos que ele vetaria (figura 03). Ou seja, vassouradas também nos projetos do parlamentares.

Seguem outros tópicos sobre setores como telefonia, energia elétrica e água. Todos com o mesmo padrão: ilustrações estilizadas, quase sempre utilizando a simbologia da vassoura. De modo geral, o discurso era o do combate ao atraso e a necessidade de moralização do Estado brasileiro, como explícito em um dos subtítulos: "A vassoura de condão liberta São Paulo de seus vícios quatrocentões”. A utilização da expressão vassoura de condão dá o tom de mágica, que remete ao inusitado, repentino, às ações janistas, que estariam, dessa forma, em conformidade com as necessidades do crescimento acelerado vivenciado. O novo era anunciado a partir da comparação com os países do primeiro mundo, conforme podemos auferir do texto introdutório:

Felizmente, já não é mais indispensável que atravessemos o Oceano Atlântico em busca de bons exemplos para o administrador indígena. $\mathrm{O}$ modelo inglês de condução dos negócios públicos acaba de ser implantado em São Paulo, estado que, por uma estranha ironia da sorte, é o mais profundamente atingido por essa tão propalada e avassaladora crise de crescimento. (O Cruzeiro, 17 nov. 1956, p. 116. Grifo nosso).

A mensagem extraída de tal texto é a de que o desenvolvimento de São Paulo, superior às demais regiões, também havia chegado à política, permitindo, inclusive, sua comparação com os países desenvolvidos do mundo ocidental. Na luta civilizadora entre o modelo indígena e o inglês, São Paulo, através de Jânio Quadros, havia conseguido impor a vitória do segundo sobre o primeiro. Era a vitória do mundo civilizado sobre o mundo selvagem. Jânio era, ainda, o símbolo do bandeirante, emissário da civilização. 
A defesa do "Jânio gladiador”, feita pela revista, acentua a necessidade de ações práticas independentes da máquina estatal. Nesse sentido, defendia o Jânio “criador de casos”, diante dos políticos que, apesar de criticarem a administração pública, não tomavam nenhuma medida efetiva, aguardando soluções legislativas moderadas. O poder pessoal e seu controle direto sobre os funcionários era elogiado, defendendo os famosos despachos via "bilhetinhos”. Anunciava ainda que Jânio não precisava aguardar pela reforma administrativa para promover as mudanças no Estado, afirmando que: "para quem não quer “criar casos”, a reforma administrativa é uma solução, mas para quem deseja pôr em ordem uma nação levada do diabo como a nossa, não haverá tempo sequer para redigir o prólogo da aludida reforma” (O Cruzeiro, 17 nov. 1956, p.120) Era, portanto, na avaliação da revista, necessário banir o passado, representado em parte por uma burocracia lenta e ineficiente, por um Estado inchado por práticas clientelistas “de 400 anos” e implantar um novo modelo que garantisse, sobretudo, a eficiência nos moldes do mundo capitalista, que se impunha como hegemônico no Brasil da época. A urgência de tais medidas, diante do acelerado movimento do progresso, permitia, inclusive, a defesa de uma democracia, um tanto distinta, que defendia, muitas vezes, medidas autoritárias, alegando que eram a sua garantia.

No ano seguinte, os feitos de Jânio em São Paulo continuaram a ser exaltados na revista. Duas reportagens têm como título introdutório “Tire o Chapéu a São Paulo” (O Cruzeiro, 24 ago. 1957 e 07 dez. 1957). As duas são muito parecidas, tendo inclusive o mesmo tamanho - cinco folhas duplas, mais meia página, sendo possivelmente matéria paga. Entretanto, não é nosso objetivo responder a estas questões, mas somente analisar a imagem construída do político e sua prática política na revista. Estas são reportagens, sobretudo fotográficas, sendo as fotografias orientadoras da leitura. Elas têm o objetivo principal de constituírem-se em "provas" concretas do desenvolvimento promovido por Jânio Quadros em São Paulo, retratando as obras realizadas.

A primeira delas enfocou a pavimentação de estradas de rodagem, sendo permeada de fotografias - vinte e três ao todo - de estradas recém pavimentadas ou em obras (fig.04 e 05). Tratores e trabalhadores compunham os cenários, reforçando a idéia de trabalho. Fotos aéreas de várias estradas no Estado indicavam o mapa das obras realizadas. Na página central, uma fotografia maior ocupava as duas páginas: era a ponte sobre o Parapanema, ligando o norte do Paraná a São Paulo, elevada, nessa reportagem, à categoria de obra-prima, símbolo das realizações do Governo (fig.06).

A tônica aqui é o tempo. Tempo que se acelerava, que impunha outras formas de medi-lo, como a velocidade possibilitada pelas novas estradas, cuja construção era fruto do 
progresso técnico e da eficiência administrativa. Nesse sentido, texto e legendas são ricos em expressões como "Jânio Quadros está quebrando todos o recordes administrativos do país”; São Paulo faz em 4 o que a República fez em 68 anos”; "Nenhuma barreira detém a marcha do progresso paulista”; "pavimentação em tempo recorde”; “Trinta meses depois de empossado [...] fez milagres” e assim por diante.

Este novo tempo seria também de uma nova política, cujo modelo mais acabado era o do governo paulista de Jânio Quadros, como podemos deduzir do texto:

Porque Jânio é uma geração no poder. Geração nova. Jânio é a mocidade que se realiza como equipe dirigente. Pensando, agindo e reagindo como pensa, age e reage a juventude. Equacionando em novos termos os velhos problemas nacionais. Abandonando a comodidade do conservadorismo clássico. Por isso também Jânio é incompreendido, atacado, fustigado, caluniado até por aqueles que fogem, de boa ou má fé, do entendimento do fenômeno. Fenômeno de que o atual governo paulista significa revolução sem sangue, é a imposição de novos métodos, é a adoção de novos caminhos, é um grito de afirmação de todos os moços do Brasil. Grito que será impossível abafar. (O Cruzeiro, 24 ago. 1957, p. 90)

A nova política tanto construía quanto era construída por um novo cenário, unindo, assim, espaço e tempo num mesmo ideal, numa mesma imagem da nação:

Quem voa sobre São Paulo observa a olho nu que o território paulista foi transformado numa verdadeira usina: trabalha-se dia e noite nas suas estradas, e o ronco dos tratores, a fumaça das unidades preparadoras do asfalto, o andar imponente de pesadas máquinas, o avanço dos rolos compressores proporcionam um sono tranqüilo ao contribuinte bandeirante que sabe onde e como está sendo empregado seu dinheiro. (O Cruzeiro, 24 ago. 1957, p. 90).

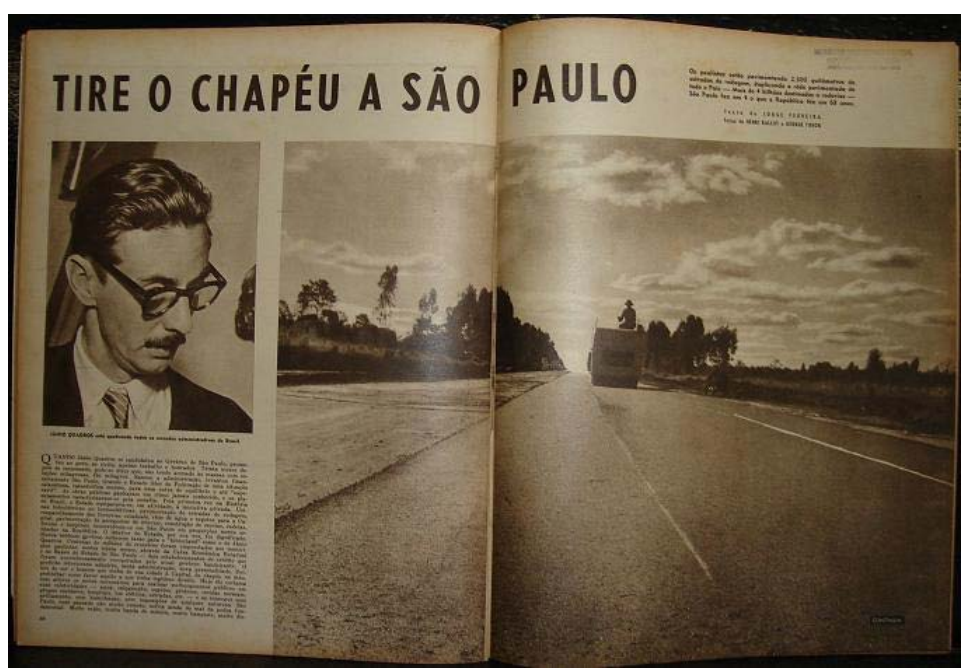


Figura 04: Tire o Chapéu a São Paulo. O Cruzeiro, 24 ago. 1957. p. 88-89.

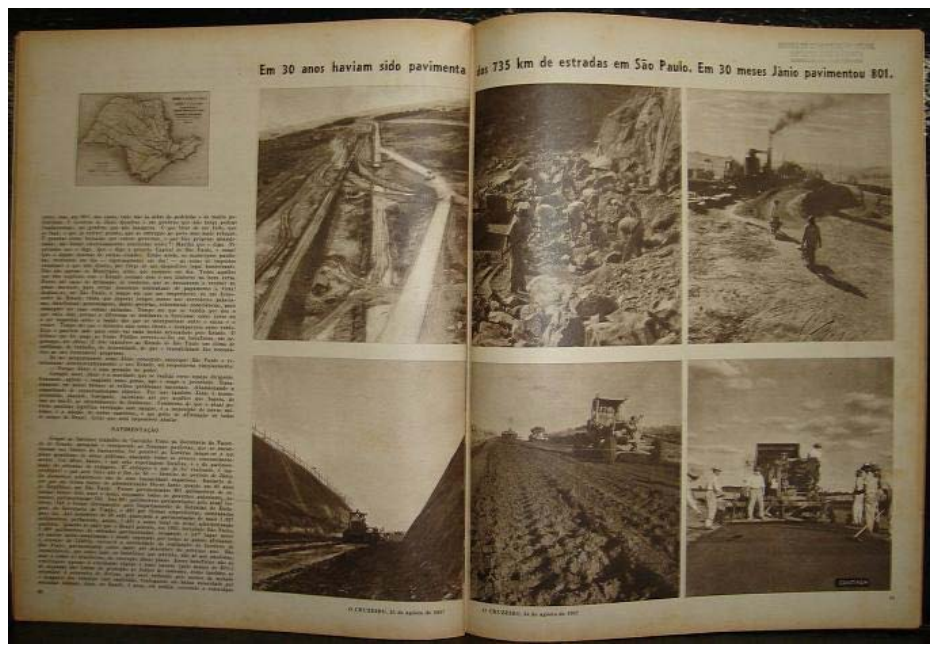

Figura 05: Tire o Chapéu a São Paulo. O Cruzeiro, 24 ago. 1957, p. 90-91.

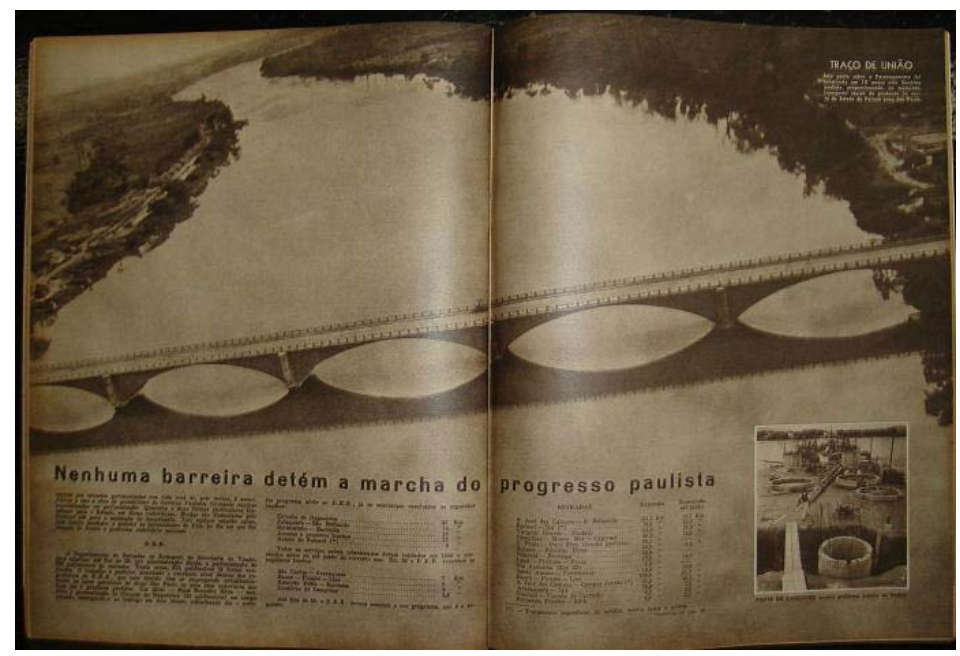

Figura 06: Tire o Chapéu a São Paulo. O Cruzeiro, 24 ago. 1957, p. 92-93.

\section{JK - o presidente simpático}

Se Jânio aparecia como exemplo de político, através de suas ações em São Paulo, Juscelino era a expressão nacional que simbolizava a nova geração. De um lado, ele incorporava a imagem de um presidente moderno; de outro, um trabalhador incansável, comprometido com o desenvolvimento econômico acelerado do país. 
É importante lembrar os fatores diretamente ligados ao apoio de Chateaubriand e da revista à Juscelino, uma vez que, ao estudarmos as representações, temos que ter em mente que ela não está dissociada de seu contexto. Sabe-se que as posturas assumidas por Chateaubriand variavam conforme os dividendos que dela poderia auferir. É com este propósito que os Diários Associados e seu carro-chefe, a revista O Cruzeiro, empenharam-se na campanha à presidência da República de Juscelino Kubitschek, cujo apelo nacionalista, ao menos na retórica, e a relação com o varguismo contrapunham-se aos ideais defendidos por Assis Chateaubriand e sua rede.

Antes mesmo do início da campanha presidencial, Juscelino havia se comprometido com Chateaubriand, que ofereceu o apoio da Rede Associada em troca de um cargo de Senador. O apoio, porém, não era gratuito, traduzia-se em anúncios pagos pelo candidato, sendo que, caso fosse eleito, resultaria em excelente fonte de renda. Era um grande negócio. Segundo Fernando Moraes (1994), Juscelino teria iniciado seu governo com uma dívida de 1,3 milhão de dólares com os Associados.

O apoio de uma ala poderosa da imprensa, como era os Associados, foi fundamental, especialmente, na conjuntura em que Juscelino Kubitschek assumiu o governo. A posse ocorreu após um conturbado processo eleitoral e uma tentativa de golpe ${ }^{7}$, sob o olhar receoso dos Estados Unidos que, através de suas empresas aqui instaladas, apoiavam claramente o candidato da UDN, Juarez Távora, pois esperavam que desse continuidade à política próamericana de Café Filho. Kubitschek, por sua vez, estava ligado a alguns ideais nacionalistas, além de ter como vice o ex-ministro do Trabalho do governo Vargas, João Goulart, que alguns ligavam aos comunistas. Entretanto, o período do governo JK foi marcado pela entrada maciça de capitais estrangeiros, sendo que, para pôr em prática o seu Plano de Metas, adotou uma estratégia clara de incentivo aos investidores, tanto nacionais quanto internacionais. $\mathrm{O}$ objetivo era integrar Estado, capital estrangeiro e empresariado nacional.

Cabe ressaltar que a divulgação das imagens, favoráveis a JK, ocorreram paralelamente a algumas críticas indiretas ao governo, especialmente às questões relativas à inflação e à política cambial, pontos inegociáveis para Juscelino. Os ataques mais diretos vieram somente no final de 1957, em um misto de artigos e reportagens de David Nasser. A crítica central era a construção de Brasília, seu elevado custo, abandono do Rio de Janeiro e o sistema de corrupção crescente que envolvia a construção da nova capital.

\footnotetext{
${ }^{7}$ A UDN e alguns militares da ESG (Escola Superior de Guerra) não aceitaram a vitória de Jucelino e Jango e tentaram um golpe de Estado, impedido pelo General Lott.
} 
Um ponto aproximava as ideias defendidas por O Cruzeiro àquelas de $\mathrm{JK}$ : o gradual afastamento de Kubitschek do "nacionalismo", enfatizando a questão que seria consenso ao longo de toda década: o desenvolvimento. Os discursos tanto de O Cruzeiro, quanto o de Juscelino convergiam para um mesmo objetivo, ou seja, o desenvolvimento do país era o único meio de realizar transformações sociais e econômicas, lembrando que o capitalismo proposto pelo Plano de Metas era associado e não independente, como propunha o governo anterior.

A ideia nacionalista, contudo, não foi de todo abandonada. O que JK pretendia era um novo tipo de nacionalismo que tirasse proveito do capital estrangeiro. Ele soube aproveitar-se do discurso varguista para fins ideológicos e táticos, o que lhe permitiu negociar com diferentes setores da burguesia e das forças políticas do país. Na mesma linha, O Cruzeiro, embora defendesse claramente a iniciativa privada e o atrelamento ao capital estrangeiro, atacando os nacionalistas, que eram descritos como xenófobos e comunistas, não podia prescindir de certo apelo nacionalista, pois necessitava estar em sintonia com a opinião pública. A questão da Petrobrás havia galvanizado o país em torno do nacional, caracterizado por Chateaubriand como discurso populista e demagógico. Entretanto, a revista era essencialmente nacional, e mesmo evidenciando modelos estrangeiros, o tema nação permeava grande parte das reportagens.

Pautado por essas questões, pontos de convergência e de divergência, interesses e jogos de poder, O Cruzeiro difundiu uma determinada imagem do político Juscelino Kubitscheck. Nas fotorreportagens ele aparecia, geralmente, em situações informais, mostrando seu cotidiano doméstico, onde eram enfatizados valores éticos e morais em relação à família e ao trabalho, identificados aos da classe média emergente. Talvez possamos encontrar, em tais matérias, o processo de construção da imagem de JK que ficou consolidada na memória nacional, ou seja, o presidente simpático, mais tarde conhecido por: "Presidente Bossa Nova” 8 .

Privilegiamos aqui três reportagens sobre JK, publicadas em $O$ Cruzeiro. Elas se empenharam em traçar um perfil tanto pessoal quanto profissional do Presidente. Uma delas narrou a sua trajetória desde menino, pobre, em Minas Gerais, até a presidência; outra era um relato de seu cotidiano já no Catete e, por fim, uma avaliação de seu primeiro ano de governo. Em grande parte, elas enfatizaram a vida privada do presidente, que se popularizou

\footnotetext{
${ }^{8}$ No final da década de 50, a expressão "bossa nova" tornou-se sinônimo de qualquer atitude ou manifestação identificada com o novo e o moderno. Movimento que também foi uma expressão da classe média carioca. Assim, Juscelino Kubitschek, o homem que queria modernizar o Brasil, foi chamado de "presidente bossa nova".
} 
exatamente por expor esse lado informal, pessoal, o que o tornou conhecido como o Presidente simpático, cordial e de hábitos simples. A revista reforçava essa imagem que, em última análise, tornava o presidente familiar, mais próximo dos brasileiros.

A primeira reportagem, “É o Presidente do Brasil” (O Cruzeiro, 04 fev., 1956, p.4), foi publicada por ocasião da posse de Juscelino Kubitschek na Presidência da República. A ênfase era o seu passado de menino pobre. Nessa reportagem as fotografias se sobrepõem ao texto escrito, orientado a interpretação do leitor.

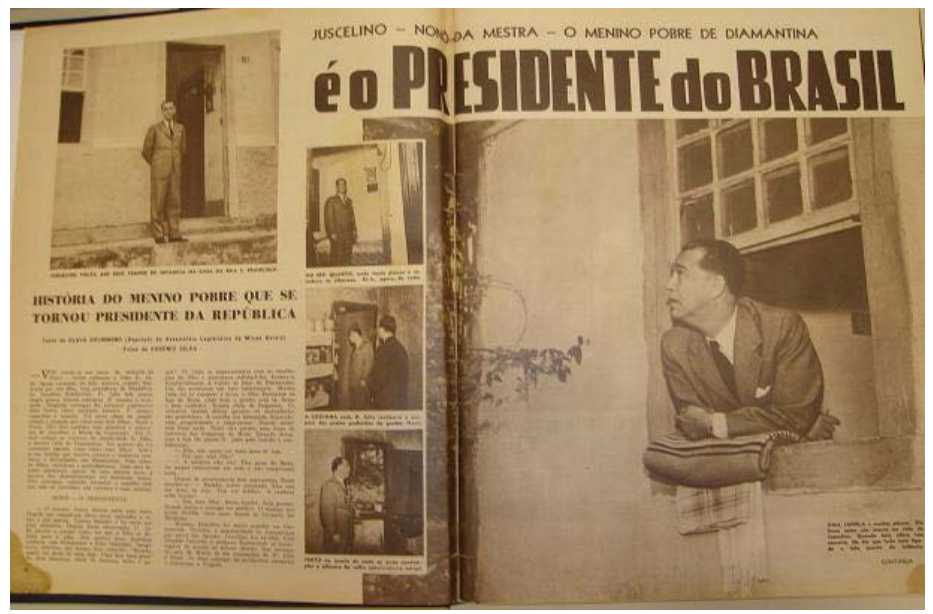

Figura 07: É o Presidente do Brasil. O Cruzeiro, 04 fev., 1956, p. 4-5.

No primeiro plano, vemos uma foto de página inteira de Juscelino, na janela de uma casa antiga e simples, com a legenda: "uma janela e muitos planos [...]” (O Cruzeiro, 04 fev., 1956, p.4). Seu olhar vai ao encontro de outras três fotografias menores, na outra página, porém integrando a mesma imagem. Nessas, ele aparece no interior da antiga residência, seu antigo quarto, cozinha; conforme as legendas identificam. No mesmo quadro visual, há outra imagem de Juscelino à porta da casa (fig.07). O conjunto completa-se com o texto sob o título: “História do Menino Pobre que se Tornou Presidente” (O Cruzeiro, 04 fev. 1956, p. 45).

Esta viagem ao passado continuou nas páginas seguintes, onde fotos antigas mostram cenas do passado do presidente, menino no seminário, onde foi, conforme as palavras do repórter, "cordial e bom companheiro"; seu trabalho como telegrafista, quando "trabalhou para poder estudar” e mais uma série de fotos organizadas em ordem cronológica, no pé da página mostram diferentes fases da vida do presidente contando sua história pessoal. No bloco seguinte, o destaque é a fotografia, em página inteira, de sua família atual com o título: “Homem de Trabalho e Pai Dedicado” (O Cruzeiro, 04 fev. 1956, p. 8-9). Seguem imagens da 
campanha presidencial, evidenciando a intensidade do trabalho. Na foto maior, ocupando todo o espaço da página, a legenda: “O governador das duas mil horas de vôo” (O Cruzeiro, 04 fev. 1956, p. 11).

Identificamos na reportagem a construção de um discurso que relacionava a trajetória de vida do presidente à dos eleitores e aos próprios rumos do país, na medida em que enfatizava a possibilidade de progredir pelo esforço individual e pelo trabalho. Miriam Limoeiro Cardoso (1978, p.94), a partir da leitura dos discursos de Juscelino, diz que eles transmitiam a crença de que éramos "um país pobre, é verdade, mas democrático; que aqui os princípios da democracia vigoram realmente e as oportunidades são iguais para todos [...]”e cita um trecho de seu discurso aos trabalhadores em 1957:

Pertenço à vossa família, porque nela nasci; não tive pai alcaide, nem parentes poderosos. Aprendi, desde cedo, que é trabalhando que nos aproximamos da virtude, conquistamos os direitos mais sagrados, entre os quais sobreleva o de sermos credores do respeito de nossos semelhantes; que trabalhando é que se honra a Deus e se dignifica a vida (CARDOSO, 1978, p. 94).

Nesse sentido, também o Brasil, um país ainda pobre, somente conquistaria a sua independência, ou seja, a sua soberania, na medida em que combatesse a pobreza, o atraso, através do trabalho e esforço. É ainda Cardoso (1978, p.94) quem cita um discurso de Juscelino no qual a identificação do desenvolvimento de sua vida pessoal ao da sociedade aparece claramente: "Notei que andara sempre sobre a linha viva do problema humano e social, sempre na faixa em que o homem, o trabalho, a profissão, a região eram, como eu, tinham sido, órfãos a carecerem de oportunidade” .

A outra reportagem refere-se não mais ao passado, mas ao presente do novo Presidente da República. A equipe de $O$ Cruzeiro passou uma semana com Juscelino, a fim de registrar seu cotidiano, tanto doméstico quanto profissional. A revista, nesse caso, interagia com o fato, sendo que os repórteres tornavam-se, ao mesmo tempo, narradores e agentes do evento narrado, na medida em que entravam no cotidiano do presidente, que, por sua vez, "construía” uma realidade adequada à sua presença.

A reportagem “JK o Pé-de-Boi” (O Cruzeiro, 04 ago., 1956, p. 104) ${ }^{9}$ inicia com uma foto do presidente no banheiro, de roupão, barbeando-se, seguida de outra, vestindo as meias (fig.08). Às cenas de intimidade (refeições, banho, etc) seguem as das atividades profissionais. A disposição de muitas fotos pequenas do presidente, em vários momentos de

\footnotetext{
${ }^{9}$ Obs.: A expressão Pé-de-Boi pode denotar, entre outras coisas, a simplicidade.
} 
trabalho, dá uma ideia de dinamismo, o que é reforçado pelas legendas e textos. "O presidente corta o cabelo no avião” é uma das chamadas e tema de uma foto, evidenciando a ideia de trabalho (fig.09).

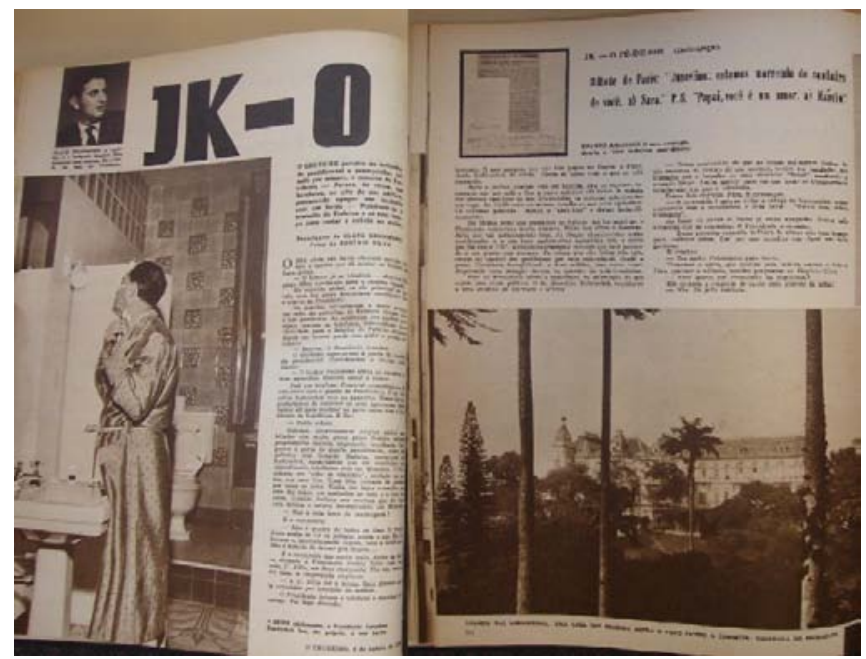

Figura 08: JK o Pé-de-Boi. O Cruzeiro, 04 ago. 1956, p. 104-112 (primeira e última páginas).

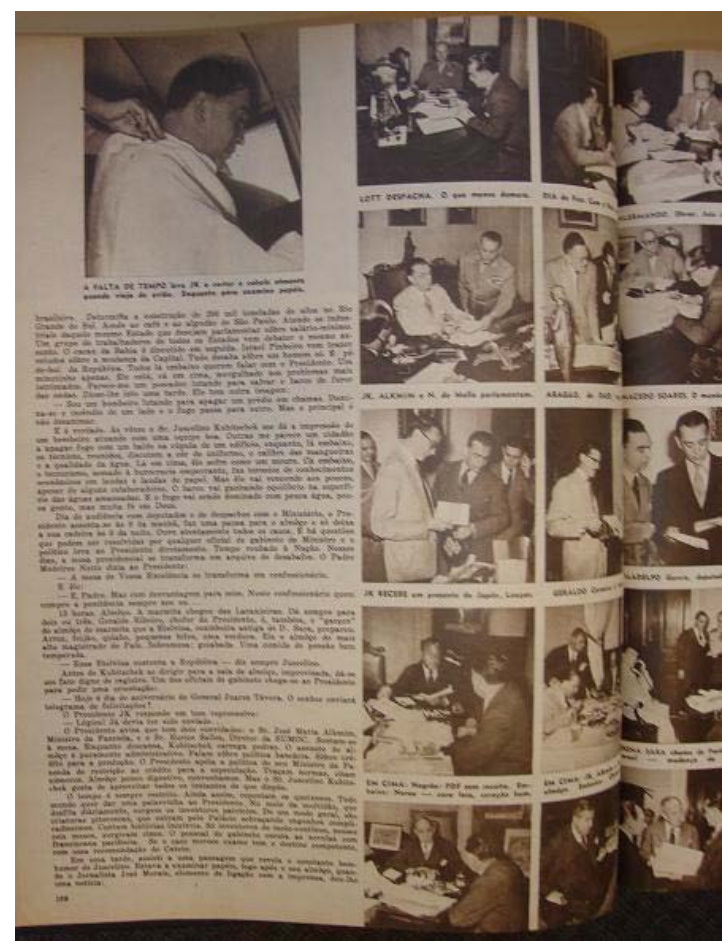

Figura 09: JK o Pé-de-Boi II. O Cruzeiro, 04 ago. 1956, p. 108-109.

Após um ano de governo, a revista publicou uma reportagem que fazia uma espécie de balanço do governo. Embora as dificuldades também fossem apontadas, lembrando 
novamente a necessidade de combater o "espectro Vargas", a imagem do governo e governante era positiva e possuía um tom progressista.

A reportagem iniciava com a fotografia de um presidente simpático e receptivo à imprensa. Com muitos repórteres, munidos de rádios transmissores, aglomerados a sua volta, JK aparece calmo, risonho, atendendo aos jornalistas (fig.10). A legenda orienta o leitor nesse sentido: "Dos presidentes da República, JK foi que teve mais contato com a imprensa [...]" $(O$ Cruzeiro, 02 fev. 1957, p. 74). No texto, lemos uma breve avaliação do período, atribuindo as dificuldades de cumprimento de suas metas sobretudo à oposição muito presa ainda ao passado e à dicotomia varguismo/ anti-varguismo. A conclusão era positiva, afirmando que o presidente havia conseguido, ao menos, “imunizar o país contra o germe da desordem, despertando nas massas o espírito do culto à defesa do regime democrático” (O Cruzeiro, 02 fev. 1957, p. 74C).

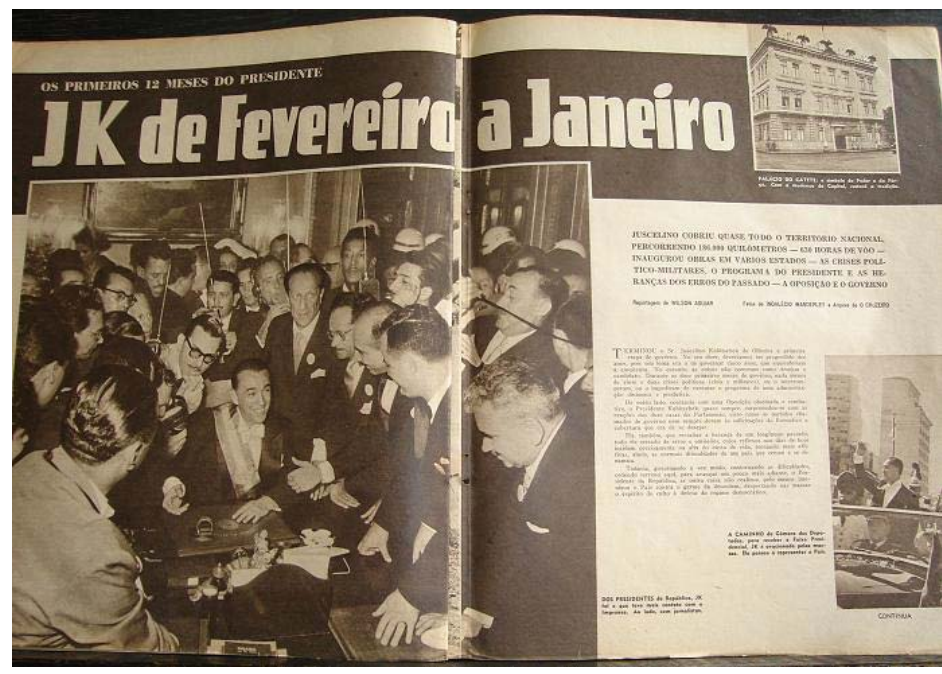

Figura 10: JK de Fevereiro a Janeiro . O Cruzeiro, 02 fev. 1957, p. 74B -74C).

A luta pela democracia foi apresentada nas páginas seguintes. Sob o título: “As crises militares e políticas foram a característica do primeiro ano do governo JK” (O Cruzeiro, 02 fev. 1957, p. 74D-E), apresenta-se uma série de fotografias - pequenos quadros representativas dos diferentes momentos de conflito enfrentados pelo governo no período As cenas retratadas foram: greve dos estudantes; rebeldia do General Juarez Távora; espada presenteada à Lott pela sua resistência ao golpe; os “casos” criados por Adhemar de Barros; os ataques de Lacerda, Jacarecanga, Almirante Amorim do Vale que teria hostilizado o governo JK pela imprensa e mais três fotos dos tumultos na Câmera, criados pela oposição. O combate às forças oposicionistas desenvolviam-se como numa história em quadrinhos. Os quadros representavam etapas que o presidente teve que superar para chegar, por fim, à 
“pacificação”. É oportuno lembrar, como nos indica Benevides (1981), que a capacidade de “administrar” essas crises foi uma das marcas do governo JK, que negociava com a oposição. As "forças do mal”, que Jânio combatia com a vassoura, JK o fazia através da diplomacia, caracterizando uma política procurou a conciliar o velho e o novo; as elites e as massas.

A reportagem finaliza com duas grandes imagens: um mapa do Brasil com o traçado dos locais visitados por JK e sua imagem acenando da escada do avião (fig.11). O mapa com as rotas das viagens do presidente, ao lado de sua fotografia “em viagem”, constrói a imagem da nação em expansão, sendo que ela ocorria pelas mãos do presidente, viajante, comunicativo e simpático. O mapa é a representação do poder/atuação de Juscelino sobre o território nacional. A construção valoriza algumas áreas, ao mesmo tempo em que marcava os limites da civilização. ${ }^{10} \mathrm{O}$ mapa não evidencia somente a integração do território nacional, mas também deste com a América Latina. Em uma imagem menor, porém no mesmo quadro visual, é mostrado um mapa da América Latina com as rotas das viagens presidenciais no continente, representando, assim, a política panamericana iniciada pelo governo e que culminará com a criação da Operação Panamericana (OPA) em 1958.

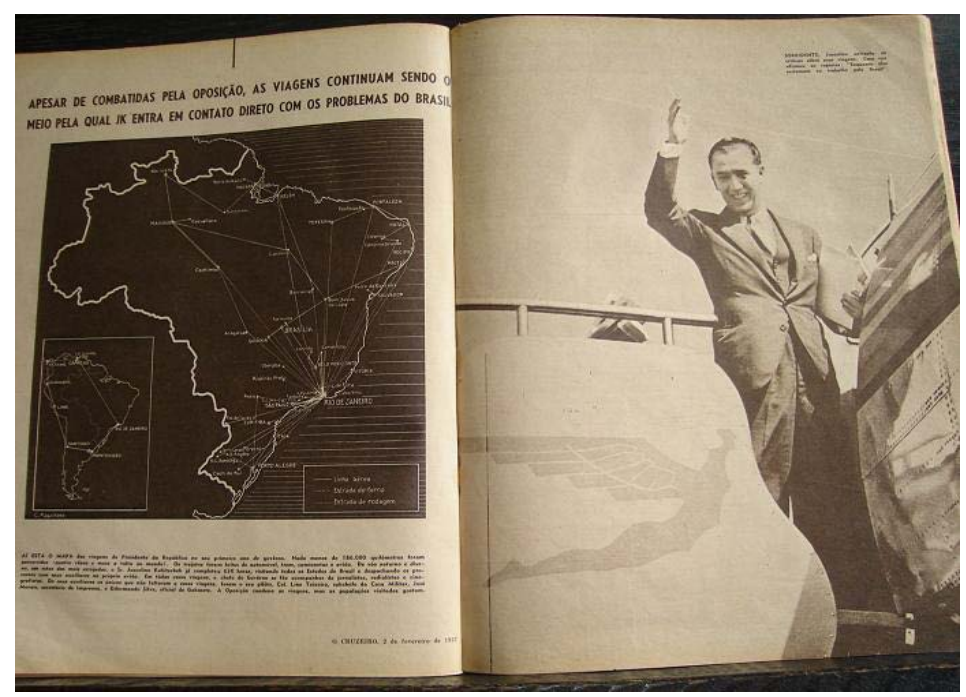

Figura 11: JK de Fevereiro a Janeiro IV. O Cruzeiro, 02 fev. 1957, p. 74H-I.

A revista $O$ Cruzeiro contribuiu, assim, para a construção de uma determinada imagem de JK, não desvinculada de suas ações e de sua própria concepção de político, de democracia e de "progresso”. Como nos diz Ângela de Castro Gomes (2002, p.16), ele

\footnotetext{
${ }^{10}$ Lembramos que entendemos o espaço como uma representação cultural, e os mapas enquanto artefatos culturais, prenhes de subjetividade e, especialmente, das marcas do poder.
} 
construiu várias imagens simpáticas à população. Foi o presidente "bossa-nova”, o presidente “peixe vivo", o presidente que gostava de voar e de sonhar [...]”.

As reportagens não aprofundam as discussões sobre os projetos econômicos ou políticos do país. Essas são discutidas na seção Política. Aqui, as informações estão em conformidade com os objetivos das fotorreportagens, ou seja, informações gerais, rapidamente digeríveis, a um público amplo, parte do qual comprava a revista para consumila nas horas de lazer. A vida do presidente, assim, integra todo um conjunto de reportagens sobre os personagens da coluna social, moda, o mundo de Hollywood, crimes, conhecimentos gerais sobre o mundo e o país. A mensagem que se sobressaía nas reportagens sobre Juscelino era a de um presidente que encarnava um novo modelo de político, jovem, moderno, mais próximo da sociedade civil, indo ao encontro as afirmações de Benevides (1981, p.29), sobre a personalidade de JK, para quem "o talento de JK consistia na provocação de um "estado de espírito” de esperança e otimismo.” Expressava um novo tipo de populismo, mais moderno, que dimensionava "pragmaticamente a ampliação da participação política através do voto [...]”.

\section{A espada do General Lott}

João Roberto Martins Filho (2003, p.121), diz que “as Forças Armadas constituíam parte integrante e indissociável do poder político desde 1930 e, principalmente, depois de 1937”. Esta participação dos militares na política é vista como um processo crescente de fortalecimento da classe no período. Os momentos de crise político-institucional, vivenciados pelo país, iam pouco a pouco colocando os militares no círculo político, à medida que eram, com cada vez mais frequência, chamados a intervir.

A presença dos militares e, mais especificamente, do General Lott foi fundamental para a estabilidade do governo JK, conforme afirma Benevides (1981). A autora destaca a importância do General, que foi um dos dois ministros a permanecer no cargo durante todo o mandato do presidente, sendo que já era o Ministro da Guerra do governo anterior, de Café Filho. O apoio incondicional de Kubitschek às Forças Armadas, e em especial ao seu Ministro da Guerra, decorria da necessidade de garantir seu projeto prioritário, o desenvolvimento econômico, só possível através da manutenção da ordem. Cardoso (1978, p.183), também atribui a participação das Forças Armadas no governo JK ao componente “ordem”, presente 
na ideologia desenvolvimentista juscelinista. Para a autora, a perspectiva política do desenvolvimento era "mudar, dentro da ordem, para garantir a ordem”.

O General Henrique Teixeira Lott foi alçado a herói nacional em 1955. A popularidade do General deveu-se ao fato de ele ter liderado o famoso contra-golpe preventivo de 11 de novembro, levantando a bandeira da legalidade democrática. “Começava o culto à personalidade de Lott. Jorge Ferreira (2003, p. 325), escreve que uma das representações utilizadas pelo jornal Última Hora para definir o general era a de "Soldado da lei”.

A despeito da divisão entre os militares, que levou ao episódio do "contragolpe”, a postura do General Lott, a favor da manutenção da ordem democrática, teve amplo apoio popular. Diversos setores da sociedade civil e da imprensa manifestaram-se neste sentido: a União Nacional dos Estudantes, empresários, Federações da Indústria, intelectuais, entre outros, repudiavam o movimento golpista. Grupos organizados mobilizaram-se prólegalidade, fundando a "Liga da Defesa da Legalidade”. Entretanto, setores ultradireitistas do exército e membros da UDN apoiavam os golpistas, sendo seu principal porta-voz a Tribuna da Imprensa, de Carlos Lacerda.

Após o episódio do 11 de novembro, Lott tornou-se herói também das esquerdas, especialmente do PTB. Foi nesse sentido que foi fundada, no início de 1956, a Frente de Novembro, organização que congregava militares tanto oficiais quanto sargentos, sindicalistas, petebistas e comunistas, unidos em torno dos ideais do nacionalismo e da democracia. Ferreira (2003, p, 326) diz que o general Lott surgiu como principal personagem do movimento. O PTB tentava, assim, ganhar a oficialidade para a causa trabalhista.

Não destoando da opinião pública, O Cruzeiro colaborava na construção do herói, mesmo considerando a aproximação da esquerda, comumente em campo político oposto àquele defendido pela revista e por Chateaubriand. Entretanto, a ênfase da revista era no personagem Lott, cultuado enquanto defensor da democracia, regime entendido como próprio das nações desenvolvidas e do mundo civilizado. Contribuía para isso o fato de Lott destacarse no cenário político exatamente pelo seu personalismo, colocando a disciplina e o respeito acima de posições partidárias. Ele próprio havia se manifestado contrário à candidatura de Jango, porém, ganha a eleição, viu-se obrigado a defender sua posse. E, apesar do apoio (no episódio do 11 de novembro) inclusive dos comunistas, ele era um ferrenho anticomunista. 
É nesse contexto que o próprio Chateaubriand solicitou a um de seus repórteres que elaborasse uma matéria sobre o General, por ocasião do aniversário do "Contragolpe”, em 1956. A reportagem intitula-se “Lott responde a Falcão” (O Cruzeiro, 17 nov. 1956, p. 52) ${ }^{11}$.

A reportagem só possui uma fotografia do General, em sua mesa de trabalho, sendo que as temáticas tratadas foram sintetizadas num grande subtítulo em negrito, que apresentou desta forma as posições do General: "De modo algum posso admitir as idéias do comunismo" - Também não admite o Ministro da Guerra: ateísmo, luta entre as classes, domínio da coletividade por uma minoria tirânica, cerceamento absoluto da liberdade de opinião e "outros não menores absurdos” (O Cruzeiro, 17 nov. 1956, p. 53). A reportagem iniciava descrevendo o caráter quase apolítico de Lott, que devotara sua vida à caserna. Afirmava que ele só protagonizou os eventos políticos em questão, porque foi levado a tal pela conjuntura, e o fez pelo dever militar de manter a ordem institucional, sendo descrito como o "Homem que salvou o Regime”.

Após a apologia ao herói, seguem-se perguntas e respostas sobre diversos temas da época, inclusive, sobre sua postura em relação ao capital estrangeiro, ao que ele respondeu ser favorável a uma opção mista. Ao final, sua resposta à pergunta: “Acha que o Brasil vai bem?” vai ao encontro à imagem da nação que, como vimos, a revista procurou construir e difundir:

Creio que não poderia ir melhor. Na realidade, sob a chefia de um brasileiro dinâmico e patriota, o Presidente Juscelino Kubitschek, a nação prospera em ritmo acelerado. Sobem os índices de progresso. As dificuldades reinantes são conseqüência, em grande parte, de um crescimento que se processa com rapidez. Há, é claro, problemas complexos a resolver, que afetam, sobretudo, a vida das classes menos favorecidas. Mas as soluções serão encontradas, desde que o patriotismo e a boa vontade se coloquem acima das subalternas cogitações do personalismo e do ódio. A ordem, o trabalho e o bom-senso construirão nossa grandeza. É questão de tempo.”(O Cruzeiro, 17 nov. 1956, p. 54).

Esta representação dos militares, como "não políticos”, atuando apenas como árbitros que intervêm em momentos de crise, como um "poder moderador", era a imagem historicamente construída na sociedade brasileira pelos próprios militares. No entanto, as Forças Armadas foram mudando sua postura e assumindo cada vez mais posições políticas. Após o agosto de 1954, houve uma transformação na natureza do papel das Forças Armadas, que deixaram de ser instrumento do Estado, para compor o próprio Estado, sendo que o

\footnotetext{
${ }^{11}$ Reportagem de Armando Falcão, deputado do PSD.
} 
General Lott, conforme afirma Benevides (1981, p.153), foi o que melhor explicitou a mudança na sua natureza.

Esta interferência de Lott é afirmada por Benevides (1981, p.179), que diz que durante o governo Kubitschek, houve "intensa intromissão do Ministro da Guerra em questões extramilitares - oficiais e oficiosas [...]”. Para a autora, a não intromissão alegada era, na verdade, a não intromissão conflitante, uma vez que o ministro, em troca de apoio às questões propriamente militares, dava sustentação incondicional às medidas, sobretudo às medidas econômicas do governo, o que fica explícito na reportagem acima descrita.

Em outra reportagem percebe-se a construção da imagem heróica de Lott como defensor da democracia. Em “O Brasil vacinado contra o golpe” (O Cruzeiro, 12 maio 1956, p. 14), foi reproduzida uma entrevista com Lott em que o repórter iniciava o texto dizendo ser a intenção da entrevista "registrar declarações do Ministro da Guerra sobre a situação brasileira e obter dados para transmitir aos leitores uma imagem de vida do homem que desde novembro se tornou o polo das atenções e de atração do interesse popular”, tornando-se “o mais importante homem público brasileiro do momento” (O Cruzeiro, 12 maio 1956, p.15)

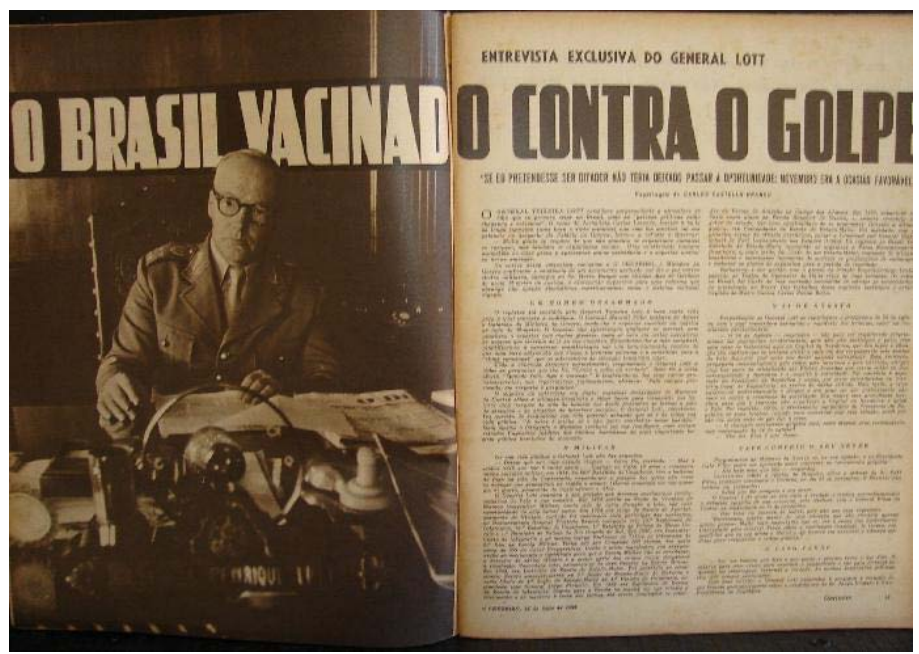

Figura 12: O Brasil vacinado contra o golpe. O Cruzeiro, 12 maio 1956, p. 14-15.

A reportagem contém duas fotografias de página inteira que registram a mesma cena da reportagem anterior. O general sentado em sua mesa de trabalho em meio a muitos papéis. A imagem escura e o ar sério de Lott conotam a seriedade e rigidez atribuída ao personagem (fig.12). Diferente do sorridente Juscelino, a imagem de Lott era austera, condizente com o seu papel de guardião da ordem democrática.

A reportagem construía a figura do General Lott como um escudo, protetor da democracia diante das crises que permearam o primeiro ano de governo de JK. Questionado 
sobre as agitações, responde dizendo serem elas “uma fase da evolução”. Tratava-se de negar qualquer envolvimento de Lott com grupos golpistas e, especialmente, com os trabalhistas e comunistas. Perguntas foram feitas diretamente neste sentido, as quais o General tratou de responder com a negativa justificada.

O General Lott, eleito como um dos heróis nacionais do momento, simbolizava, entre outras coisas, o estágio pelo qual a revista entendia estar passando o país. Nesse, a democracia deveria ainda ser garantida pela espada. Não é à toa que ela foi escolhida como o símbolo concreto, quando membros da "Frente de Novembro" entregaram uma espada de ouro como homenagem pelos serviços prestados à democracia brasileira. Este episódio foi abordado em uma reportagem de $O$ Cruzeiro. Entretanto, não há menção sobre os promotores do evento, ou seja, grupos da esquerda nacionalista, atacados frequentemente na revista. ${ }^{12}$ Embora a referência ao custo da espada, na reportagem, possa ser entendida como uma crítica sutil, não há qualquer contestação ao merecimento do General Lott. O que ficou registrado foi a imagem-símbolo da "espada de novembro" e a imagem de Lott representou, na revista, a presença e a importância que as Forças Armadas adquiriram no governo Kubitschek, enquanto garantia da democracia e do desenvolvimento econômico. Assim, entendemos que a representação política do Brasil construída e difundida pela revista estava associada à presença/interferência dos militares.

Podemos dizer que a vassoura de Jânio, a simpatia de Juscelino e a espada de Lott constituíram-se em símbolos que ajudaram a construir, nas fotorreportagens da revista $O$ Cruzeiro, uma determinada imagem da democracia brasileira do final dos anos 50, uma democracia sob a égide da espada, assinalando a fragilidade democrática da época.

Se os anos 50 ficaram conhecidos, sobretudo, pelo desenvolvimento econômico acelerado e pela ênfase no debate atraso versus desenvolvimento, politicamente este discurso traduziu-se no embate autoritarismo versus democracia. Ambos os debates, porém, podem ser entendidos como produtos de um mesmo contexto histórico da sociedade brasileira, aquele da afirmação e consolidação da ordem burguesa-capitalista, no Brasil, nos moldes das nações capitalistas desenvolvidas do Ocidente.

\section{Referências}

\footnotetext{
${ }^{12}$ Esta homenagem prestada ao General Lott foi bastante contestada por setores militares anti-11 de novembro, desencadeando uma crise no governo. O resultado foi o fechamento da "frente de novembro" e do "Clube da lanterna”, associação golpista. O episódio expôs a divisão das Forças Armadas, e o fechamento de um centro de esquerda e um de direita manteve o relativo equilíbrio e a autoridade do general Lott. BENEVIDES, Maria Victória de Mesquita. O Governo Kubitschek: desenvolvimento econômico e estabilidade política. 3 ed. Rio de Janeiro, Paz e Terra, 1979.
} 
BAITZ, Rafael. Um continente em foco: a imagem fotográfica da América Latina nas revistas semanais brasileiras (1954-1964). São Paulo: FFLCH/USP, 2003.

BENEVIDES, Maria Victória de Mesquita. A UDN e o Udenismo: As ambigüidades do liberalismo brasileiro (1945-1965). Rio de Janeiro: Paz e Terra, 1981.

O Governo de Jânio Quadros. São Paulo: Brasiliense, 1982.

. O Governo Kubitschek: Desenvolvimento econômico e estabilidade política. 3.ed.

Rio de Janeiro: Paz e Terra, 1979.

O Governo Kubitschek: a esperança como fator de desenvolvimento. In: GOMES, Ângela de Castro. (org.) O Brasil de JK. Rio de Janeiro: Editora FGV, 2002.

BOURDIEU, Pierre. O Poder Simbólico. 10.ed. Rio de Janeiro: Bertrand do Brasil, 2007.

CARDOSO, Miriam Limoeiro. Ideologia do Desenvolvimento - Brasil: JK - JQ. Rio de Janeiro: Paz e Terra, 1978.

CARNEIRO, Glauco. Brasil, Primeiro. História dos Diários Associados. Brasília: Fundação Assis Chateaubriand, 1999.

CHARTIER, Roger. O Mundo Como Representação. In.: CHARTIER, Roger. À Beira da Falésia: A história entre certezas e inquietudes. Porto Alegre: Editora da Universidade UFRGS, 2002.

CHATEAUBRIAND, Assis. Economia Tropical. Artigo publicado nos órgãos dos Diários Associados em 27 dez. 1957. In: CHATEAUBRIAND, Assis. O Pensamento de Assis Chateaubriand. Brasília: Fundação Assis Chateaubriand, 2001. v. 4.

ELIAS, Norbert. O processo civilizador. Formação do Estado e Civilização. Rio de Janeiro: Jorge Zahar Editor, 1993. v. 2.

ESPIG, Márcia Janete. O uso da fonte jornalística no trabalho historiográfico: O caso do Contestado. Estudos Ibero-Americanos. PUCRS, v. XXIV, n, 2, dezembro, 1988, p. 269-289.

FERREIRA, Jorge. Crises da República: 1954, 1955 e 1961. In. FERREIRA, Jorge; DELGADO, Lucilia de Almeida Neves. (org.). O Brasil Republicano. O tempo da experiência democrática: a democratização de 1945 ao golpe civil-militar de 1964. Rio de Janeiro: Civilização Brasileira, 2003, pp 301-342.

GAVA, José Estevam. Momento Bossa Nova: Arte, cultura e representação sob os olhares da revista O Cruzeiro. Tese apresentada ao Programa de Pós-Graduaçào em História da Faculdade de Ciências e Letras (UNESP-Assis), 2003. In.:

http://www.biblioteca.unesp.br/bibliotecadigital/document/?view=2504.

GOMES, Ângela de Castro. (org.). O Brasil de JK. Rio de Janeiro: Editora FGV, 2002.

KOSSOY, Boris. Fotografia e História. São Paulo: Ática, 1989. 
MARTINS FILHO, João Roberto. Forças Armadas e política, 1945 - 1964: a ante-sala do golpe. In. FERREIRA, Jorge; DELGADO, Lucilia de Almeida Neves. (org.). O Brasil Republicano. O tempo da experiência democrática: a democratização de 1945 ao golpe civilmilitar de 1964. Rio de Janeiro: Civilização Brasileira, 2003, pp 97-126.

MAUAD, Ana Maria. Fotografia e história, possibilidades de análise. In. CIAVATTA, Maria; ALVES, Nilda (org.). A leitura de imagens na pesquisa social: história, comunicação e educação. São Paulo: Cortez, 2004, pp 19-36.

MORAES, Fernando. Chatô, o rei do Brasil. São Paulo: Companhia. das Letras, 1994.

MOREIRA, Vânia Maria Losada. Os anos JK: Industrialização e modelo Oligárquico de desenvolvimento rural. In. FERREIRA, Jorge; DELGADO, Lucilia de Almeida Neves. (org.). O Brasil Republicano. O tempo da experiência democrática: a democratização de 1945 ao golpe civil-militar de 1964. Rio de Janeiro: Civilização Brasileira, 2003, pp. 155-194.

NEVES, Lucília Almeida. In. BENEVIDES, Maria Vitória. O governo Kubischek: O desenvolvimento econômico e estabilidade política - 1956-1961. Rio de Janeiro: Paz e Terra, 1976.

PEREGRINO, Nadja. O Cruzeiro: a revolução da fotorreportagem. Rio de Janeiro: Dazibao, 1991.

SAES, Décio. Classe média e política no Brasil, 1930-1964. In: FAUSTO, Boris; HOLANDA, Sérgio Buarque (Org). Brasil Republicano: sociedade e política. Rio de Janeiro: Bertrand Brasil, 1997, pp.448-506.

SKIDMORE, Thomas. Brasil: de Getúlio a Castelo (1930-1964). São Paulo: Paz e Terra, 2000 .

SOUZA, Jorge Pedro. Uma história crítica do fotojornalismo ocidental. Chapecó: Grifos; Florianópolis: Letras Contemporâneas, 2000. 